\title{
CORRECTION
}

\section{Correction to: Age associated decline in the arcuate fasciculus and IQ}

\section{Toshikazu lkuta $^{1} \cdot$ Hannah M. Gollnick ${ }^{1}$. Anna N. Rutledge ${ }^{1}$}

Published online: 3 August 2019

(C) Springer Science+Business Media, LLC, part of Springer Nature 2019

\section{Correction to: Brain Imaging and Behavior}

https://doi.org/10.1007/s11682-019-00154-z

The author found a mistake in their published article. The sentence "The search region was limited within each side of the white matter." should read as "The search regions was limited within each side of the white matter at and above $Z=0$."

The original article has been corrected.

Publisher's note Springer Nature remains neutral with regard to jurisdictional claims in published maps and institutional affiliations.

The online version of the original article can be found at https://oi.org/ 10.1007/s11682-019-00154-Z

Toshikazu Ikuta

tikuta@olemiss.edu

1 Department of Communication Sciences and Disorders, University of Mississippi, Oxford, MS, USA 